\title{
Levels of Manifestation of Typological Similarity in Proverbs of Different Languages
}

\author{
Elena I. Seliverstova \\ Saint Petersburg State University \\ University Embank., 7/9, St. Petersburg, Russian Federation, 199034 \\ selena754@inbox.ru
}

The relevance of this article is due to the contradiction between the typical position of linguoculturologists, who use proverbs in their studies to illustrate the idea of the national specific mental representations of the world, reflected in the language, on the one hand, and the undeniable similarity in the verbal, logical and semantic structures of the proverbs that we observe when comparing the proverbial material of completely different languages - related and not related: English, German, Russian, Czech, Bulgarian, Chinese, Turkish, Armenian, etc. The object of analysis is composed of proverbs as units by means of which the speakers express their attitude to the world in a figurative form and manifest themselves as carriers of a certain culture. This rapprochement is carried out in several directions. We note the undoubted similarity (1) in the field of thematic areas, chosen to state the results of observation and conclusions, which generalize the experience gained and derive pragmatic meaning from it; (2) at the level of proverbial condensates (mental constructs, ideas) that briefly convey the contents of the proverb - such as "A wife and a husband are different", "A child inherits the properties of parents", "A little bad thing spoils a big good", etc.; (3) at the level of generalized concepts - the signs of them are especially actively reflected in proverbs: the image of gold in its various interpretations is universal - as a standard of a high degree of any characteristic, as a way of solving many life difficulties, etc.; (4) at the level of components that verbalize concepts, become sustainable elements of proverbs, can be opposed or compared. Binomial pairs form the logical and semantic structure of proverbs ("friend" — "alien", "smart" — "stupid", "head" "legs"), move from one unit to another and some of them can have different verbal implementations ("predator" - "victim": wolf - lamb/sheep/cow). This analysis allows us to talk about coincidences not only in assessing the importance of individual objects and phenomena, in thoughts about them and associations, in the spectrum of identifiable signs, in verbalization techniques used for matching generalized ideas, and - at last - about a certain reduction in the pathos of the statement about the national specificity of the proverbial space of the particular language.

Key words: proverb, different languages, thematic sphere, concept, proverbial condensate, binomial pair, similarity

\section{Article history:}

Received: 25.01 .2020

Accepted: 01.02.2020

\section{(C) Селиверстова Е.И., 2020}

(c) (1) This work is licensed under a Creative Commons Attribution 4.0 International License https://creativecommons.org/licenses/by/4.0/ 


\title{
For citation:
}

Seliverstova, E.I. (2020). Levels of Manifestation of Typological Similarity in Proverbs of Different Languages. RUDN Journal of Language Studies, Semiotics and Semantics, 11(2), 198-212. doi: 10.22363/2313-2299-2020-11-2-198-212

УДК 811.161.1’37:81’44:398.91

\section{Уровни проявления типологического сходства в пословицах различных языков}

\author{
Е.И. Селиверстова \\ Санкт-Петербургский государственный университет \\ Университетская наб., 7/9, Санкт-Петербург, Российская Федераџия, 199034 \\ selena754@inbox.ru
}

Актуальность данной статьи обусловлена противоречием между типичной позицией лингвокультурологов, использующих в своих исследованиях пословицы для иллюстрации идеи национальной специфичности ментальных представлений о мире, отражающихся в языке, с одной стороны, и неоспоримым сходством в вербальной, логической и семантической структурах пословиц, которое мы наблюдаем при сравнении пословичного материала разных языков - родственных и отнюдь не родственных: английского, немецкого, русского, чешского, болгарского, китайского, турецкого, армянского и др. Объект анализа составляют пословицы как единицы, посредством которых говорящие выражают в яркой образной форме свое отношение к миру и проявляют себя как носители определенной культуры. Это сближение осуществляется в нескольких направлениях. Мы отмечаем несомненное сходство (1) в области тематических сфер, избираемых для констатации результатов наблюдения и выводов, которые обобщают полученный опыт и выводят из него прагматический смысл; (2) на уровне пословичных конденсатов (ментальных конструктов, идей), кратко передающих содержание пословицы - таких, как "Муж и жена различаются", "Ребенок наследует свойства родителей”, "Маленькое плохое портит большое хорошее" и др.; (3) на уровне обобщенных концептов, признаки которых особенно активно отражаются пословицами: универсальным является образ золота в разных его трактовках - как эталона высокой степени проявления какого-либо признака, как способа решения многих жизненных затруднений и т.д.; (4) на уровне компонентов, которые вербализуют концепты, становятся устойчивыми элементами пословиц, могут сравниваться или противопоставляться. Биномы формируют логическую и семантическую структуру пословиц (свой - чужой, умный - глупый, голова - ноги и т.д.), переходят из одной единицы в другую и могут иметь различные вербальные воплощения (волк - ягненок/ овца/ баран). Это позволяет нам говорить о совпадениях не только в оценке важности отдельных предметов и явлений, в мыслях о них и ассоциациях, в спектре выявляемых признаков, в приемах вербализации совпадающих обобщенных представлений, но и - в конечном итоге - о некотором снижении пафоса утверждения о национальной специфичности пословичного фонда отдельного языка.

Ключевые слова: пословица, различные языки, тематическая сфера, концепт, пословичный конденсат, биномиальная пара, сходство

\section{История статьи:}

Дата поступления: 25.01.2020

Дата приема в печать: 01.02.2020

\section{Для цитирования:}

Селиверстова Е.И. Уровни проявления типологического сходства в пословицах различных языков // Вестник Российского университета дружбы народов. Серия: Теория языка. Семиотика. Семантика. 2020. Т. 11. nо 2. С. 198-212. doi: 10.22363/2313-2299-2020-11-2-198-212 
The reports of national uniqueness of proverbs

have been greatly exaggerated

\section{Introduction}

In any language there are expressions - idioms, clichéd phrases, proverbs, sayings, quotes - which are frequently repeated and known to all native speakers of the language. They reflect the national spirit and ethnically specific image of the world [1. P. 95-96; 2. P. 214-215]. Nowadays phraseology and paremiology are usually considered as a treasury of national color of any literary language. This idea can be traced back to the XIX century when active searches for evidence of national identity of the people were conducted [3. P. 8].

In the XX century the Polish linguist Anna Wierzbicka made an attempt to reveal the unique traits of national mentality by interpretation of language units, including idioms and proverbs [4]. Her enthusiasm became an impulse for an active search for national specificity, for "a linquistic image of the world".

Based on this position, it is easy to see in Russian expression как Мамай прошел (liter. "as if Mamay has passed; something looks like ruins after Mamay's campaign"), a reminder about historical event - the invasion of khan Mamay and the Golden Horde to Russia in XIII-XIV centuries which led to devastation of Russian lands. This idiom is used in the meaning of 'big disorder, something upside-down, in a mess'. This historical precedent is reflected in English expression Scratch a Russian and you find Tatar which reminds of the Tartar Mongol Yoke in Russia.

The Russian idiom остаться у разбитого корыта ("to be left with the broken wash-tub" - 'to be left with nothing, to lose everything'; 'to be back where one started') may seem meaningless to a person who does not know Alexander Pushkin's fairy tale about a greedy old woman who asked a magic Goldfish to fulfill her three desires. Having asked too much, the old woman lost everything she received and turned poor again. Thanks to this story, this expression characterizes a situation when all the plans and hopes are crushed and life returns to the initial state.

Now there are numerous works of modern linguists, specialists in folklore, cognitive scientists in which one finds an explanation to such language units from the point of view of their connection to historical events, ethnographic facts, cultural codes and literary contexts hidden in such expressions. Similar facts of the language, which is "an organ of original thinking and perception" (V. von Humboldt) for representatives of each ethnic group, allow us to understand how mental and linguistic division of reality correlate and how, under the influence of certain factors, "the processes of categorization and conceptualization of ideas about the world" are reflected in the linguistic picture of the world [5. P. 98].

In the framework of the cognitive approach to the language and its units, phraseology is considered as a field of linguistics, in which in the closest way "the language, culture, history and world picture of a particular ethnic group are intertwined" [6. P. 139], and, therefore, phraseological units act as signs of ethnomarked information, manifested in the figurative and expressive-evaluative perception of objects of the world. 
A quantum of nationally-labeled information is contained in the Russian proverb Чем лаптю кланяться, так уж поклонюсь сапогу ("I'll better bow to a boot, than to a bast shoe"), which expresses contempt towards the lower class inhabitants of a village. The meaning of the expression becomes clear, if the speaker knows the different symbolical value of the bast shoe and the boot in the folklore. These items and the words designating them became signs of a social status. Bast shoe ('the cheapest, manually made footwear used by peasants') costs close to nothing, and that is why this word is associated with a negative meaning 'An ignorant, uncivilized, backward person'; rich people wore boots. The shoe motif also became the basis of other proverbs about equality and inequality - not necessarily in social context, it can be used to express various human qualities: Лапоть сапогу не товарим ("The bast sandal is not a friend of the boot"); Лапоть знай лаптя, сапог сапога ("Let the bast shoe befriend its own kind, and so the boot") [7. P. 56]. The contemptuous look upon the countrymen who usually wore bast shoes was also reflected in the phraseological unit не лаптем щи хлебать ("One doesn't eat soup with a bast sandal"), i.e. 'someone has reached notable success; he is able to do something well and he's proud'.

Proverbs from this point of view are especially interesting, because, on the one hand, they contain the images which are associated with cultural and national standards, stereotypes, codes and mythemes and express the mentality which is specific for a certain lingvocultural community [8. P. 175]. On the other hand, the units (elements) of proverbial wisdom are a feature of the special conceptual thinking of native speakers, because they represent real judgments and are the seeds of modernized meanings that are important for speakers.

For example, the image of a person who is praying in front of an image of God down on one's knees is universal, but it is in Russian culture that the lack of a sense of proportion and a reasonable attitude to this action, which leads to a broken head, is regarded as a sign of stupidity. The proverb Заставь дурака Богу молиться, он и лоб разобьет ("Make the fool pray to God, and he will smash his forehead") is used as an expression of frustration from a spoiled case, discontent, distrust of the performer. It characterizes someone's exaggerated and unsuccessful attempt to do something.

The study of cultural phenomena reflected in the language, carried out mainly on the material of two languages - Russian against the material of French [9], Japanese [10], Czech [11], Udmurt [12], Chuvach [13], Chinese [14], or more comparable languages $[15,16]$, is usually accompanied by a significant emphasis on the national identity of the studied cultures, which is manifested, inter alia, in phraseological and proverbial units.

P.M. Eismont, analyzing the mental images of the hare and the rabbit among Russians and English and comparing them, notes both the richness of the culturalassociative background that was formed among the native speakers of two languages, and its specificity, which is determined to a large extent by the influence of phraseological units, proverbs, precedents texts, ceremonies, etc., as well as by differences in units verbalizing this background [17. P. 47-49].

Meanwhile, upon closer examination of the paremias and their features in different languages - both typologically close and absolutely completely unrelated in their 
origin, it becomes obvious that, in addition to the differences, a significant number of common points are observed in the paremiology of different ethnic groups.

\section{Materials and methods}

The number of multilingual dictionaries has significantly grown up during the recent years. Among the comprehensive collections of XX-XXI centuries in this field are to be mentioned the collections of J. Gluski (1971 [18]), M. Kuusi (1985 [19]), Sprichwörter (1990 [20]), G. Paczolay (2002 [21]), etc. Back at the beginning of the XXI century, W. Mieder noted that the extant bibliographies of proverb collections have registered over 20,000 volumes with about 200 new publications each year [22. P. XII]. The numerous proverb collections make it possible to study proverbs on a comparative basis.

In this paper, we use the data from the following dictionaries: L. Trup [23], V. Vinogradova, D. Grechushnikova [24], J. Bachmannová, V. Suksov [25], J. Gluski, as well as the "Great Dictionary of Russian Proverbs" [26], "Chinese phraseological dictionary" [27], "Dictionary of People's Proverbs and Sayings of the East" [28], "Dictionary of Turkish Proverbs" [29], "Armenian folklore" [30].

In this paper, we rely on theoretical studies which have been undertaken by Matti Kuusi, Peter Gzhibek, Wolfgang Mieder, Kazys Grigas, Arvo Krikmann, etc., who tried to find answers to the questions connected with the similarity and the differences in the nature and functioning of proverbs in different languages became the real base for the comparative researches of proverbs.

We consider, after A. Dundes, that the proverb is "a traditional saying that sums up a situation, passes judgment on a past matter, or recommends a course of action for the future. $<\ldots>$ Proverbs consist of at least one topic and one comment about that topic" (compare: Money talks) [31]. This definition can be clarified by the following details: this anonymous expression has a sentence structure, some attributes of a genre (a model, a form, a rhythm, a rhyme) and contains moral teaching or an insight from life, a rule which expresses a timeless modality [32. P. 22-24].

\section{Research results}

Let's move on to the analysis of different languages in order to show that the proverbial fund of the language, uniting the whole society and adopted by it, is in any respects in contact with proverbial funds belonging to other peoples and cultures. ${ }^{1}$

Carefully regarding the proverbs in various languages one can see that the reports of national uniqueness of proverbs have been exaggerated.

I. First of all, one can find expressions which are not connected with the national identity, but appeared on the all-European cultural and philosophical basis and have a common origin - mythology, the Bible, fiction, etc.

\footnotetext{
${ }^{1}$ For reasons of economy, we will use abbreviations instead of the full names of the languages: Rus. - Russian, En. - English, D. - Deutsch, Fr. - French, Cz. - Czech, Turk. Turkish, Chin. - Chinese, Armen. - Armenian, etc.
} 
For example, the Russian expression Не рой другому яму, сам в нее упадешь (Eng. He who digs a pit for others falls in himself), originating from the Bible, has equivalents in the majority of the European languages (more than 20 languages):

D. Wer andern eine Grube gräbt, fällt selbst hinein; Fr. Qui conduit dans le fossé, tombe le premier; Sp. Quien hace un hoyo para otro, el sae en el hoyo; Lat. In fovean cecidit, quam fecerat ipse; Cz. Kdo jinému jámu kopá, sám do ní padá; Turk. El için kuyu bazan kendi düşer içine; Bulg. Kойmо копае гроб другиму, сам пада в него, etc.

Another expression which became an ideological slogan in the Soviet Russia also originates from the Bible: Kто не работаem, mот не ест (Eng. He that will not work shall not eat). This was paradoxical for a country which dissociated itself from religion. Compare equivalents: D. Wer nicht arbeitet, soll auchht essen; Fr. Celui qui ne veut pas travailler ne doit pas manger; Cz. Kdo nepracuje, ten neji; Turk. Çallşmayan aç kalır; Eng. If one doesn't work, doesn't eat; Chin. 不勞動者, 不得食, etc.

II. However, in different languages we often find proverbs which are not based on genetic commonness or language contacts, and which, however, have much in common in their meaning, structure and vocabulary. This can be explained by the common features of the human nature and intellectual activity and common observations of the environment.

The degree of typological similarity of proverbs is usually detected in three levels, - thematic, semantic and conceptual. But a wide proverbial sphere is built not only by the proverbs themselves, which enter into various relations with each other, but also by many so-called "fragments" of a different scale (or constituent parts) of the proverbs - on the one hand, more fractional (typical components, structural models, cliched formulas) and, on the other, - more generalized, "superproverbial" ideas ("mental condensates").

Let us mention here successively some points (elements) that demonstrate typological similarities in the proverbs of various European languages.

A. For example, traditionally compared are related expressions — proverbs about family, work, friendship, drunkenness, etc., united by one topic. Here one can hardly find any essential differences: after all, in each language there are expressions about money, age, happiness, love, illnesses, etc., because these are basic, universal, vital things. To verify that, it is enough to look at thematic headings in proverbial dictionaries of different languages and in multilingual dictionaries. In a six-lingual dictionary by J. Gluski, which contains over 1100 proverbial phrases in each of the six languages, the whole corpus is divided into 48 topical sections: Truth-Lie, Business-Trade, Knowledge-Experience, Time-Weather, Happiness and Misfortune, Borrowing-Debts, etc. [18, P. XXXVIII]. In the dictionary "Proverbs of the Russian People" published by a famous Russian lexicographer V.I. Dal [33], one finds almost the same division of proverbs. Subjects like the relationship between friends and spouses, the attitude to one's own property and someone else's, wealth, vengeance, are very widely presented in proverbs of many languages. Although any subject can be reflected in proverbs of various languages and cultures with different degree of occurrence and directions of specification.

Many proverbs reflect the complex relations between the daughter-in-law and the mother-in-law (D. Des Mannes Mutter, der Frauen Teufel "The husband's mother is the wife's devil"; Eng. The mother-in-law remembers not that she was a daughter- 
in-law). But in Russian and Chinese languages one can find a full proverbial encyclopedia revealing different aspects of these relations: Rus. Блудливая свекровь и невестке не верит ("The lascivious mother-in-law doesn't trust the daughter-inlaw"), Свекровь кошку бьет, а невестке наветки дает ("Mother-in-law tips off the daughter-in-law by beating a cat"), Сноха за порог, свекровь за пирог ("Motherin-law starts eating a pie only after daughter-in-law leaves"), etc.

Chin. 媳婦踏著婆鞋印。(“The daughter-in-law steps on a trace from a boot of the mother-in-law”), 婆婆打媳天下有。(“The mother-in-law beats the daughter-inlaw, it is a usual situation”), 一個媳婦十個婆婆。(“For one daughter-in-law <it is possible to give $>$ ten mothers-in-law"), etc. [34].

B. Similarities and distinctions between proverbs can be discovered at the level of concepts denoted in them. A complex of proverbs reveals the ideas that the native speakers have about realities which exist in their environment — both material and mental. The image of gold should be recognized as universal, it has become a benchmark of priceless quality, a powerful "instrument" that helps to achieve a lot, opens up wide possibilities for a person: Rus. Золотой молоток железные ворота прокyem ("A gold hummer can open an iron gate"); Eng. A golden key will open every lock; Cz. Na zlatou udici snadno ryby lapati ("Easy to fish with a gold fishing rod"); Dobrá žena je lepši nad zlatý sloup ("A good wife is better than a golden pillar"); Arm. "Education is like a gold bracelet on a hand", etc.

The German scientist Harry Walter notes the universality of concepts Soul and Heart for different nations of the world [35. P. 15].

There is a more prosaic example. The pig, according to proverbs, appears in many languages as an unworthy, gluttonous, lazy, fat, dangerous, noisy animal. But the association of the pig with dirt and danger, which exists in Russian (Свинья грязи найдет - liter. "The pig will always find dirt"; Наряди свинью хоть в серьги, а она все в навоз пойдет - "If you dress a pig in earrings, she will still go to manure"), is absent, for example, in Chinese.

On the other hand, one would find images of tiger and elephant in the languages spoken by people, who can observe these animals in nature, live close to them. As a rule one can hardly come across an image of tiger in Russian proverbs, whereas in the imagery of Asian proverbs it is quite rampant: Korean: "Whether the dog or the monk — to a hungry tiger it's all the same"; Bengal. "In water there is a crocodile, ashore - a tiger"; Indones. "He who looks like a tiger, is a little mouse in his soul". This image is also widely represented in Chinese language: "Two tigers don't live in one wood"; "If you want to touch the bum of a tiger, it is necessary to understand his temper before", etc.

III. The share of uniquely national elements in the proverbial corpus of a certain language becomes less significant, if, while comparing different languages, one takes into consideration special features of proverbs as such. Here are these features.

1. If in our mind we exclude the "decoration" element from a proverb (i.e. its metaphoric qualities, lexical redundancy, rhythm, rhyme, etc.), the pure essence of the expression may be revealed as a predicative structure consisting of two or three components and expressing the summarized main idea of the proverb. The term "proverb" can hardly be applied to such a structure, because these expressions lack 
the necessary proverbial markers. However, it can be called a "proverbial condensate" or "proverbial idea".

For example: "An experienced person is reliable", "An old person can be wrong", "Work can be delayed", "Things that have been said can't be taken back", "A wife and a husband are identical", "You can't cure a fool", "A quiet (reserved) person could be dangerous", "Something big is better than small", etc. These structures produce such new concepts as logema $(\leftarrow$ logic, logical $)$ and cognitema $(\leftarrow$ cognitive, cognition), which denote proverbial ideas and their fragments [see: 36. P. 57-60].

In the light of the data contained in dictionaries it becomes obvious that many ideas have no uniquely national coloration at all: they are international. The generalized idea "The child is similar to the parent" ("The descendant is similar to the ancestor") is present in proverbs of almost all languages. The idea of similarity can be expressed as follows:

— via images of an apple and an apple-tree (or fruit and tree) ${ }^{2}$ : Rus. Яблоко от яблоньки недалеко падает (liter. "The apple doesn't fall far from the apple-tree"); D. Der Apfel fällt nicht weit vom Stamm; Cz. Nepadne jablko daleko od stromu; Bulg. Ябълката не пада далеч от дънера си; Fr. Tel arbre, tel fruit; Eng. As the tree so the fruit; Like tree, like fruit;

— via images of animals and their babies: Rus. Не родится от свиньи бобренок, всегда - поросенок ("The pig can't give birth to a baby-beaver, always to a babypig"); Vietn. "If father is lion, his son is a young lion"; Armen. "A donkey will grow from a baby-donkey”; Chin. 虎父無犬子 “The tigress can’t give birth to a mongrel”;

- without the use of figurative elements: Rus. Какова мать, такова и дочь ("The daughter is just like her mother"); Eng. Like mother, like daughter; Indones. "A speckled father has a speckled son"; Azerbajd. "The descendant is just like the ancestor”; Chin. 有其父 必有其子 (“Like father like son”).

The proverbial idea "The one who has been frightened earlier, now is careful" reveals nearly universal notion of caution based on experience. Various types of great and small dangers are depicted in proverbs: Rus. Обжегшись на молоке, на воду dyem ("The one who was burned by milk, now blows on water"); Korean "The one who got frightened by a tiger, now is afraid of a cat"; Turk. "The one who was burned by milk, now blows on yogurt"; Bulg. "The one who was bitten by a snake, now is afraid of a lizard"; Chin. "The snake bites you once, and ten years you are still afraid of a string"; Cz. "The scalded rooster even escapes from a rain"; Armen. "Who was bitten by a motley snake, he is afraid of a motley rope".

In multilingual dictionaries the proverbs are united by the following principle: (a) at first - thematically (the last examples are connected with the topic "Care, Distrustfulness, Foresight"), and (b) then - according to the way the idea is expressed "The one, who has negative experience, is careful".

\footnotetext{
${ }^{2}$ The expression, probably, goes back to the Bible, where there is a quote about the compliance of different trees and fruits.
} 
Through the example of proverbs with the meaning "Everyone praises his own property" we will trace the convergence of the expressions from various languages which have different figurative meanings:

\begin{tabular}{|c|c|c|c|c|c|}
\hline & Every & $\mathbf{x}$ & praises & His/its <own> & $\mathbf{y}$ \\
\hline Eng. & Every & cook & praises & his own & broth \\
\hline Rus. & Every & $\begin{array}{c}\text { wood- } \\
\text { cock }\end{array}$ & praises & its & bog \\
\hline Sp. & Every & potter & praises & his & pot \\
\hline $\mathrm{Cz}$ & Every & bird & praises & its own & feathers \\
\hline It. & Everyone & & praises & his & profession \\
\hline D. & Everyone & & praises & & himself \\
\hline
\end{tabular}

2. Secondly, proverbs in various languages often reveal similarity at the level of the opposed generalized concepts which form the logical structure of proverbs and their meaning. In proverbs the notions "strong" _ "weak", "small" _ "big", "beautiful" _ "ugly", "predator" _ "victim", "work" — "payment", "stupid" — "clever", "one" — "two", etc., are opposed or connected to each other, but can have different verbal implementations.

In every language the proverbial idea "Something small can spoil something big" has several figurative implementations, in which pairs of opposed generalized concepts could easily be found: "small $\leftarrow \rightarrow$ big" and "valuable $\leftarrow \rightarrow$ bad, disgusting" that form the meaning of a proverb [37. P. 109-116]. For example: Rus. Ложка дегтя портит бочку меда ("A spoon of tar spoils a barrel of honey"); Eng. One drop of poison infects the whole tun of wine; Sp. "A small amount of bile does bitter a lot of honey"; It. "One drop of a wormwood spoils a vase of honey"; Cz. "A small amount of bile spoils a whole goose".

The proverbial condensate "One of many spoils <all $>$ the others" which is expressed, in particular, via images of apples or sheep, is a variant of the idea described above:

(1) Eng. The rotten apple injures its neighbours; It. Una mela Marcia ne guasta cento ("One apple spoils one hundred");

(2) Rus. Одна паршивая овиа все стадо портит (“One nasty sheep spoils the whole herd"); Eng. One scabbed sheep will mar a whole flock; D. Ein räudiges Schaf steckt die ganze Herde an; It. Una pecora marcia ne guasta un branco; Sp. Oveja infestada infesta a la manada ("An infected sheep infects the herd");

Turk. Bir kötünün yedi mahalleye zarart vardır ("One bad lot ruins a whole street"); Armen. "One mouse spoils seven tuns with wine".

If we compare the proverbs of different languages that contain the following pairs of components - a wolf - a sheep, a bear - a cow, a fox - a chicken, a cat - a mouse, it becomes clear that they are connected with the identical relations "predatorvictim" [see: 38. P. 183-184]. Proverbs about the wolf and the sheep we find in Russian, Czech, Armenian, Chinese and other languages: Rus. Отольются волку овечьи слезки ("The wolf will be responsible for the sheep's tears"); Armen. "You can't trust a lamb to a wolf"; Chin. "The hungry wolf is not punished, the herd of sheep is not calm". 
Almost all European languages have proverbs about cats and mice: Rus. Kот из дому - мылии в пляс ("If the cat leaves the house, the mice dance"); Fr. Absent le chat, les souris dansent; Eng. When the cat's away, the mice will play; Sp. Vanse los gatos, y entiéndense los ratos; D. Ist die Katz aus dem Haus, rührt sich die Maus, etc.

3. Similarities of concept's verbal envelopes and their combinations in proverbs of various languages are quite noticeable. On one hand, they reveal the real connections between objects and phenomena (leg and hand, wolf - teeth, cow - milk, war - peace, mouse - bread, husband - wife, smoke - fire, work - money, horse - bridle). On the other hand, they also reveal the associations which man forms through comparison, search for similarity and understanding of observed objects and their role in life. This allows us to talk about typical proverbial "binomials" [see: 39].

The head, as a part of the body or as a metaphorical "tool" for thought generation, can be associated, as the proverbs show, with various things: the head - cap, beard, brains, language, hair, neck, back, tail, etc. Compare, for example, in English: A big head and little wit; One head and ears in debt; When the head ached, all the body is the worse; Better be the head of a dog, than the tail of a lion; Keen eyes are small gain in the head without brain; The head grey and no brains yet.

One will find expressions which mention head and feet in many languages:

Eng. Little wit in the head makes much work for the feet; It. Chi non ha testa ha gambe ("The one who has no head, has got feet"); Cz. Kdo nemá v hlavě, musí mít v nohou ("The one who has no <brain> in the head, has to work with the feet"); Turk. Akılsız başın cezasını ayaklar çeker ("Dough head makes legs get tired"); Rus. Дypная голова ногам покоя не дает ("The bad head doesn't allow the feet to have a rest"); Где мужчина ногою, там женщина не доправит и головою ("Where a man's foot can help, a woman's head won't be enough"), etc.

The association of the woman with the devil, though very peculiar, is also present in several languages: It. La donna unata prima del diavolo ("The woman was born before the devil"); Eng. Where the devil can't come, he will send a woman; D. Wo der Teufel nicht hin mag, da schickt er ein altes Weib ("Where the devil doesn't want to go, he sends an old woman"); Rus. Баба да бес-один в них вес ("The woman and the devil have an equal weight"); Cz. Kam čert nemůže, tam strči ženskou ("Where the devil can't not come, he will send a woman"); Turk. Erkeğin Şeytanı kadın. ("It's a woman who is a man's devil"); Port. O que o diabo não pode, consegue-o a mulher ("If the devil cannot do it, the woman will master").

\section{Conclusion}

Thus, we can sum up some results. From the foregoing, the denial of the national originality of the certain people's proverbs does not at all follow as a conclusion. Undoubted differences in the perception of the world and its reflection in the proverbial arrays of different languages are found:

- in the nominative density of units expressing the same idea in each of the compared languages; "A way of transmitting thoughts (ideas) in a word" [40. P. 328] and the nature of the used language means - figurative, on the one hand, and devoid of metaphors and analogies on the other; 
- in the spectrum of vectors of comprehension by speakers different languages of any phenomenon of reality, subject, act; not only in Chinese, but also in many other cultures, for example, there is no idea of snow as cheap, countless and abundant and the possibility of selling it to someone as evidence of the seller's fantastic enterprise;

- in axiological assessments given in proverbs by representatives of different cultures and constituting the "foundation of any ethnic culture" [41. P. 205]; porridge, for example, seems to be worthy food for the Russians, Koreans consider porridge to be secondary in comparison with rice, which is not porridge for them; for Germans porridge is the food of the poor, an indicator of social status.

This kind of data on proverbs in various languages certainly reflects the ethnically marked features of the national linguistic images of the world. But, perhaps, even to a greater degree, these data demonstrate perception of reality phenomena, mental constructs and metaphoric vision of the world common for the speakers of various languages and different ethnic groups.

The typological commonness and similarity of proverbs of different peoples are manifested, in particular, in the proverbial binomials, which allow to see the «association space» of the proverbial components in the paremiological sphere, and thus a peculiar way a thought is reflected in proverbs, the rules by which a proverb "manages" the knowledge of the world.

The units we've named "condensates", i.e. proverbial ideas, binomials, i.e. typical pairs of opposed logical generalized concepts, and their verbal embodiments, associations and representations reflected in proverbs - can become, just like the full proverbs, material for dictionaries of a special type that displays the ways of creating a proverbial expression.

\section{References}

1. Eismann, W. (1995). Pragmatics and cultural specificity as a problem of the equivalence of phraseologisms In From the one-word metaphor to the sentence metaphor. Bochum. (In Germ.).

2. Teliya, V.N. (1996). Russian phraseology. Semantic, pragmatic and cultural aspects. Moscow. (In Russ.).

3. Mokienko, V.M. (2013). Cognitive in diachronic and diachronic in cognitive In Cognitive factors of the interaction of phraseology with related disciplines. Belgorod. pp. 8-14. (In Russ.).

4. Wierzbicka, Anna. (1991). Cross-cultural pragmatics: the semantics of human interaction. Berlin - New York: Mouton de Gruyter.

5. Yurina, E.A. \& Baldova, A.V. (2017). Food metafor in conceptualization, categorization and verbalization about the world. Tomsk State University Journal of Philology, 48, 98-115. Doi: 10.17223/19986645/48/7. (In Russ.).

6. Soboleva, N.P. (2017). Linguoculturological aspects of the contextual use of phraseological units in advertising slogans. Tomsk State University Journal of Philology, 45, 139-149. Doi: 10.17223/19986645/45/10. (In Russ.).

7. Bierich, Alexander (1995). Metonymy in modern Russian: Semantic and grammatical aspects. München: Verlag Otto Sagner. (In Russ.).

8. Daun, Åke. (2004). Swedish Mentality. University Park: Penn State University Press.

9. Dombrovskaya, M.V. (2006). Comparison of the Russian concept "rain" and the French concept "pluie" (based on an associative experiment). Linguistica Juvenis. Language and Culture, 7, 91-106. (In Russ.).

10. Nedosugova, A.B. (2014). The concept "Strength of mind" in the Japanese and Russian phraseology, RUDN Journal of Language Studies, Semiotics and Semantics, 5(3), 55-60. (In Russ.). 
11. Seliverstova, E.I. (2019). Your own eye is a diamond, and someone else's glass: trust and mistrust among Russians and Czechs (on the example of proverbs). In Linguocultural studies. Logical language analysis. The concept of faith in different languages and cultures. Moscow: “Gnozis". pp. 281-291. (In Russ.).

12. Zvereva, T.P. (1999). On the specifics of the national-linguistic picture of the world of Russians and Udmurts (according to phraseology) In Vinogradov's readings. Cognitive and cultural approaches to linguistic semantics. Moscow. pp. 20-21. (In Russ.).

13. Kuznetsova, I.V. \& Lukina, M.R. (2016). Russian and Chuvash comparisons in a comparative aspect In Comparative units in the phraseology system. St. Petersburg-Greifswald. pp. 190197. (In Russ.).

14. Yuan', Liin. (2016). Stereotypical idea of a guest in Russian proverbs (against the backdrop of Chinese). Izvestia Volgograd State Pedagogical University, 1, 148-152. (In Russ.).

15. Paizbekova, A.D. (2015). Representation of the peculiarities of national-cultural specifities of "TIME" concept in Russian, English and Kazakh proverbs. RUDN Journal of Language Studies, Semiotics and Semantics, 6(2), 100-109. (In Russ.).

16. Bredis, M.A. (2019). Man and Money: Essays on Russian and other Proverbs. S. Petersburg: Petersburg Oriental Studies. (In Russ.).

17. Eismont, P.M. (2016). The mental image of "Rabbit" in the naïve linguistic world view. Perm University Herald. Russian and Foreign Philology, 3(35), 41-51. Doi: 10,17072/2037-66812016-3-41-51. (In Russ.).

18. Gluski, Jerzy (1971). Proverbs. A comparative book of English, French, German, Italian, Spanish and Russian proverbs with a Latin appendix. Amsterdam-London-New York: Elsevier publishing company.

19. Kuusi, Matti. (1985). Proverbia septentrionalia. 900 Balto-Finnic proverb types with Russian, Baltic, German and Scandinavian parallels. Helsinki: Suomalainen Tiedeakatemia.

20. Sprichwörter - proverbs - poslovicy (in acht Sprachen — Deutsch, Englisch, Russisch, Polnisch, Tschechisch, Französisch, Spanisch und Latein) (1990). 2. Aufl. Berlin: Volk und Wissen Volkseigener Verlag. (In Germ.).

21. Paczolay, G. (2002). European proverbs in 55 languages with Eequivalents in Arabic, Persian, Sanskrit, Chinese and Japanese. Hobard, Tasmania: De Proverbio.com.

22. Mieder, Wolfgang. (2004). Proverb: A handbook. "Greenwood Folklore handbooks". Westport, Connecticut, London: Greenwood Press.

23. Trup, L. (1993). Proverbs and sayings (in four languages - Spanish, Slovak, Czech and Latin). Bratislava: SOFA. (In Slovak.).

24. Vinogradova, V., Grechushnikova, D., Zelinsky, V., Kuchera, L., Sartre, S. and others. (2012). Multilingual dictionary of modern phraseology, D. Puccio (Ed.). Moscow: Flinta. (In Russ.).

25. Bachmannová, Jarmila \& Suksov, Valentin. (2007). As it is said elsewhere. Czech proverbs and their other-language analogies. Praha: EG Universum. (In Czech).

26. Mokienko, V.M., Nikitina, T.G. \& Nikolaeva, E.K. (2010). Great Dictionary of Russian Proverbs. Moscow: Olma media group. (In Russ.).

27. 新华 成语 词典. 北京: 商务印书馆. (2015). [Sinhua phraseological dictionary; Chinese]. Beijing: Business edit. (In Chin.).

28. Permyakov, G.L. (2001). Dictionary of people's proverbs and sayings of the East. A systematic collection of sayings of two hundred peoples. Moscow: Labirint. (In Russ.).

29. Yurtbaş1, Metin. (2012). Dictionary of Turkish proverbs. Istanbul: Excellence publishing. (In Turk.).

30. Armenian folklore. (1979). Karapetyan, G.O.( Ed.). Moscow: Publishing house of oriental literature "Nauka". (In Russ.).

31. Dundes, A. (1975). On the structure of the proverb. Proverbium, 25, 961-973.

32. Zanglinger, V. (2007). Definition of a proverb as a paremiological problem. Russian studies in Bulgaria, 1-2, 5-29. (In Russ.).

33. Dal', V.I. (2004). Proverbs of the Russian People. In two vols. Moscow. (In Russ.). 
34. 王怡君 (Wang Yi-chun). (2005). Woman and man in the mirror of Russian and Chinese proverbs [dissertation]. Taipei: Chinese culture university. (In Russ.).

35. Walter, H. (2013). The German heart and the Russian soul: are two things compatible? In Cognitive factors of the interaction of phraseology with related disciplines. Belgorod. pp. 14-20. (In Russ.).

36. Ivanova, E.V. (2002). Proverbial pictures of the world (based on English and Russian proverbs). St. Petersburg: Filol. faculty of St. Petersburg State University. (In Russ.).

37. Permyakov, G.L. (1988). Fundamentals of structural paremiology. Moscow: The Public house of oriental literature. (In Russ.).

38. Seliverstova, E.I. (2009). The experience of identifying the proverbial binomial and the problem of variation. Russian language in scientific coverage, 1, 182-200. (In Russ.).

39. Seliverstova, E.I. (2017). The space of the Russian proverb. Stability and variability. Moscow: Flinta. (In Russ.).

40. Niewiara, A. (2017). Phraseological Constructions and Mental Visual Representations. Experimental Research on the Stereotypes of Nations In World in Pictures and in Phraseology. Praha: Charles University. pp. 311-329. (In Pol.)

41. Mamontov, A.S., Cjedjendorzhijn, J. \& Boguslavskaya, V.V. (2019). A value system through the perspective of culturally oriented lexicography (on the example of Russian-Mongolian comparisons). Russian Journal of Linguistics, 23(1), 200-222. Doi: 10.22363/2312-91822019-23-1-200-222. (In Russ.).

\section{Библиографический список}

1. Eismann W. Pragmatik und kulturelle Spezifik als Problem der Aequivalenz von Phraseologismen // Von der Einwortmetapher zur Satzmetapher / Hrsg. S. Baur, Ch. Chlosta. Bochum: Universitaetsverlag Brockmayer, 1995. P. 95-120.

2. Телия B.H. Русская фразеология. Семантический, прагматический и культурологический аспекты. Москва: Школа. Языки русской культуры, 1996.

3. Мокиенко В.M. Когнитивное в диахроническом и диахроническое в когнитивном // Когнитивные факторы взаимодействия фразеологии со смежными дисциплинами: Сб. научных трудов. Белгород, 2013.

4. Wierzbicka A. Cross-cultural pragmatics: the semantics of human interaction. Berlin - New York: Mouton de Gruyter, 1991.

5. Юрина Е.А., Балдова А.В. Пищевая метафора в процессах концептуализации, категоризации и вербализации представлений о мире // Вестник Томского гос. ун-та. Филология. 2017. no 48. С. 98 -115. Doi: 10.17223/19986645/48/7.

6. Соболева Н.П. Лингвокультурологические аспекты контекстуального использования фразеологизмов в рекламных слоганах // Вестник Томского гос. ун-та. Филология. 2017. no 45. C. 139-149. Doi: 10.17223/19986645/45/10.

7. Бирих А. Метонимия в современном русском языке: Семантический и грамматический аспекты). München: Verlag Otto Sagner, 1995.

8. Daun, Ake. Swedish Mentality. Transl. by J. Teeland. University Park: Pennsylvania State University Press, 2004.

9. Домбровская М.В. Сопоставление русского концепта «дождь» и французского концепта «pluie» (на материале ассоциативного эксперимента) // Linguistica Juvenis. Язык и культура: Сб. научных трудов молодых ученых. Вып. 7. Екатеринбург, 2006. С. 56-62.

10. Недосугова А.Б. Понятие «сила духа» в японской и русской фразеологии // Вестник Российского университета дружбы народов. Серия: Теория языка. Семиотика. Семантика. 2014. по 5(3). С. 55-60.

11. Селиверстова Е.И. Свой глаз — алмаз, а чужой стекло: доверие и недоверие у русских и чехов (на примере паремики) // Лингвокультурологические исследования. Логический анализ языка. Понятие веры в разных языках и культурах. М.: Гнозис. 2019. C. $281-291$. 
12. Зверева T.P. К специфике национально-языковой картины мира русских и удмуртов (по данным фразеологии) // Виноградовские чтения. Когнитивный и культурологический подходы к языковой семантике. М., 1999. С. 20-21.

13. Кузнецова И.В. Русские и чувашские устойчивые сравнения в сопоставительном аспекте / И.В. Кузнецова, М.Р. Лукина // Устойчивые сравнения в системе фразеологии. СПб Грайфсвальд, 2016. С. 190-197.

14. Юань Лиин. Стереотипное представление о госте в русских пословицах (на фоне китайских) // Известия Волгоградского гос. пед. ун-та. 2016. по 1. С. 148-152.

15. Пайзебекова А.Д. // Вестник Российского университета дружбы народов. Серия: Теория языка. Семиотика. Семантика. 2015. по 6(2). С. 100-109.

16. Бредис М.А. Человек и деньги: Очерки о пословицах русских и не только. СПб.: Петербургское востоковедение, 2019.

17. Эйсмонт П.М. Об образе зайца в наивной языковой картине мира // Вестник Пермского университета. Российская и зарубежная филология. 2016. nо 3(35). С. 41-51. Doi: 10,17072/2037-6681-2016-3-41-51.

18. Gluski Jerzy. Proverbs. A Comparative Book of English, French, German, Italian, Spanish and Russian Proverbs with a Latin Appendix. Amsterdam-London-New York: Elsevier publishing company, 1971.

19. Kuusi Matti. Proverbia septentrionalia. 900 Balto-Finnic Proverb Types with Russian, Baltic, German and Scandinavian Parallels. Helsinki: Suomalainen Tiedeakatemia, 1985.

20. Sprichwörter — proverbs — poslovicy (in acht Sprachen — Deutsch, Englisch, Russisch, Polnisch, Tschechisch, Französisch, Spanisch und Latein). 2. Aufl. Berlin: Volk und Wissen Volkseigener Verlag, 1990.

21. Paczolay G. European proverbs in 55 languages with Equivalents in Arabic, Persian, Sanskrit, Chinese and Japanese. Hobard, Tasmania: De Proverbio.com, 2002.

22. Mieder W. Proverb: A handbook. "Greenwood Folklore handbooks". Westport, Connecticut, London: Greenwood Press, 2004.

23. Trup L. Príslovia a porekadla (v štyroch jazykoch — španielčina, slovenčina, čeština, latinčina). Bratislava: SOFA, 1993.

24. Виноградова В., Гречушникова Д., Зелинский В., Кучера Л., Сартре С. и др. Многоязычный словарь современной фразеологии. М.: Флинта, 2012.

25. Bachmannová J., Suksov V. Jak se to řekne jinde. Česká př́ísloví a jejich jinojazné protějšky. Praha: EG Universum, 2007.

26. Большой словарь русских пословиц / В.М. Мокиенко, Т.Г. Никитина, Е.К. Николаева. М.: ЗАО «Олма Медиа Групп», 2010.

27. 新华成语词典. 北京: 商务印书馆, 2015 年. Синхуаский фразеологический словарь. Пекин: Бизнес-изд-во, 2015.

28. Пермяков Г.Л. Пословиц и поговорки народов Востока. Систематизированное собрание изречений двухсот народов. М.: Издательство «Лабиринт», 2001.

29. Yurtbaşı, Metin. Sinıflandırılmış Atasözleri Sözlüğü. İstanbul: Excellence Publishing, 2012.

30. Армянский фольклор. Сост. и пер. с армянского Г.О. Карапетяна. М.: Гл. ред. восточной литературы изд-ва «Наука», 1979.

31. Dundes A. On the Structure of the Proverb // Proverbium. 1975. no 25. P. 961—973.

32. Занглингер B. Определение пословицы как паремиологическая проблема // Болгарская русистика. 2007. no 1-2. С. 5-29.

33. Даль В.И. Пословицы русского народа: в 2 т. М.: Художественная литература, 2004.

34. 王怡君 Wang Yi-chun. Женщина и мужчина в зеркале русских и китайских пословиц (диссертация). Taipei: Chinese Culture University, 2005.

35. Walter, Harry. “Немецкое сердце и русская душа: две вещи совместные?” // Когнитивные факторы взаимодействия фразеологии со смежными дисциплинами: Сб. научных трудов. Белгород, 2013. С. 14-20. 
36. Иванова E.B. Пословичные картины мира (на материале английских и русских пословиц). Санкт-Петербург: Филол. фак-т СПбГУ, 2002.

37. Пермяков Г.Л. Основы структурной паремиологии. М.: Главная редакция восточной литературы, 1988.

38. Селиверстова Е.И. Опыт выявления пословичного бинома и проблема вариантности // Русский язык в научном освещении. 2009. по 1. С. 182-200.

39. Селиверстова Е.И. Пространство русской пословицы: постоянство и изменчивость. М.: Флинта: Наука, 2017.

40. Niewiara A. Frazeologizmy a mentalne reprezentacje wizualne (badania eksperimentalne stereotypów narodów) // Svět v obrazech a ve frazeologii. Praha: Univerzita Karlova, 2017. S. 311-329.

41. Мамонтов А.С., Цэдэндоржийн Э., Богуславская М.М. Система ценностей в аспекте национально-ориентированной лексикографии (на примере русско-монгольских сопоставлений) // Вестник РУДН. Серия: Лингвистика. 2019. Vol. 23. no 1. 200-222. Doi: 10.22263/2312-9182-2019-23-1-200-222.

\section{Information about the author:}

Elena I. Seliverstova, Doctor of Philology, Professor, Professor and acting head of Russian Language Department for Humanitarian and Natural Faculties; St. Petersburg State University. Interests: Russian and Slavic phraseology and paremiology, lexicology, linguocultural studies, text linguistics, comparative studies, translation and interpretation studies; culture of Russian speech; e-mail: selena754@inbox.ru; ORCID: http://orcid.org/0000-0003-2020-0061; ResearcherID: N-2892-2013; SPIN-code: 2032-2115.

\section{Сведения об авторе:}

Селиверстова Елена Ивановна, доктор филологических наук, профессор, профессор, исполняющий обязанности заведующего кафедрой русского языка для гуманитарных и естественных факультетов Санкт-Петербургского государственного университета; научные интересы: русская и славянская фразеология и паремиология, лексикология, лингвокультурология, лингвистика текста, компаративные исследования и проблемы перевода, культура русской речи; e-mail: selena754@inbox.ru; ORCID: http://orcid.org/0000-0003-2020-0061; ResearcherID: N-2892-2013; SPIN-code: 2032-2115. 